TILTAI, 2015, 3, 149-160, ISSN 1392-3137 (Print), ISSN 2351-6569 (Online)

\title{
GROŽIO TERAPIJOS SPECIALISTŲ RENGIMAS LIETUVOJE: GROŽIO TERAPEUTO KOMPETENCIJŲ GRUPĖS
}

\author{
Jūratė Jocienè, Alicija Ramanauskaitè \\ Šv. Ignaco Lojolos kolegija
}

\begin{abstract}
Anotacija
Straipsnyje analizuojama grožio terapeuto veiklos specifika, apibrèžiamos specialiosios kompetencijos, ugdomos studijuojant grožio terapiją, aptariamas grožio terapeuto rengimas Lietuvoje, apibūdinamos grožio terapeutui būtinos asmeninès savybès ir mąstymo ịgūdžiai, pristatomos grožio terapeuto kompetencijų grupès.

PAGRINDINIAI ŽODŽIAI: grožio terapeutas, kompetencija, grožio terapijos kompetencijų grupès.
\end{abstract}

\begin{abstract}
The article analyzes the specifics of the beauty therapist work. The article discusses the beauty therapist training in Lithuania, describes the required personal qualities and thinking skills and presents the competency groups for beauty therapists.

KEY WORDS: beauty therapist, competence, groups of the beauty therapy competencies.
\end{abstract}

DOI: http://dx.doi.org/10.15181/tbb.v72i3.1173

\section{Ivadas}

Grožio terapijos paslaugų poreikis nuolat auga, ši specialybė populiari tiek darbo rinkoje, tiek tarp profesijas besirenkančių jaunuolių. Grožio terapijos profesinio bakalauro studijas Lietuvoje siūlo net keletas aukštojo mokslo įstaigų. Analizuojant grožio terapeutų veiklos specifiką pabrěžtina, kad grožio terapijos paslaugos yra gana ,jautrios“, tai ne tik grožio procedūrų atlikimas pagal taisykles. Grožio terapeutai turi sudaryti sąlygas klientui pabūti malonioje aplinkoje, užmegzti su juo teigiamą ir glaudų, nors ir trumpalaikį, ryši. Grožio terapeutui būtina išsiugdyti ne tik pagrindines profesines kompetencijas, bet ir turèti didelị bagažą bendrujų žinių, tokių kaip psichologija, kalbos kultūra, užsienio kalba, bendravimas su įvairiais žmonėmis ir pan. Be to, šios srities specialistas turi gebėti prisitaikyti prie nuolatinių jo veiklos pokyčių, kad galètų patenkinti klientų lūkesčius ir išsilaikyti darbo rinkoje, kur laukia nuolatiniai iššūkiai.

Grožio terapijos studijų Lietuvoje siekiamybė: studijas baigęs studentas turètų gebėti pritaikyti ịgytas žinias praktiškai, mokèti atlikti tyrimus, būtų ịgijęs būtinus socialinius gebejjimus, tokius kaip: komunikabilumas, konstruktyvus bendravimas, kūrybiškumas, atsakomybė. Ne mažiau svarbūs ir asmeniniai gebejjimai, profesi- 
nès nuostatos, vertybių sistema, kultūringumas, gebejjimas tobulintis ir savarankiškai ugdytis.

Darbdavių teigimu, švietimo sistema rengia specialistus pagal programas, kurios dar nepakankamai atitinka darbo rinkos poreikius, absolventai ateina ị darbo rinką nepasirengę praktiniam darbui ịgytos profesinės kvalifikacijos srityje. Kritikuojamos ir profesinio, ir aukštojo mokslo sistemos (Andriušaitienè, 2013).

A. Savanevičienè, D. Stukaite, V. Šilingienè (2008) tyre žmogiškụjų išteklių sẻkmingą integraciją daugiakultūrèje Europos darbo jègos rinkoje ir pažymėjo, kad mokslinèje literatūroje teoriniai kompetencijų ir jų ugdymo aspektai nagrinèti plačiai. Tačiau D. Staliūnienè (2009) atkreipia dėmesị ị tai, kad šios tyrimų kryptys dažniausiai ribojasi darbuotojų kompetencijos ugdymo problemomis organizacijos poreikių kontekste, individo kompetencijų ugdymo poreikiams ir esamų ugdymo programų tobulinimui skiriant antraeilị vaidmenị.

Nors grožio terapeuto (kosmetologo) profesija pasaulyje turi senas veiklos, mokymo(-si) ir ugdymo veiklai tradicijas, šios srities specialistai su profesinio bakalauro diplomu Lietuvoje pradèti rengti vos prieš keletą metų. Lietuvos mokslininkai tik fragmentiškai tyrinèja grožio terapeutų (kosmetologų) ugdymo praktiką ir kompetencijas. Dirbančių kosmetologijos specialistų kvalifikacijos kẻlimo poreikị tyrinėjusios V. Isiūnienè, G. Adomavičienè, Ž. Mickienè (2012). J. Jocienė, Ž. Navikienè, J. Valiulienė (2014) parengè „Kosmetologijos ir grožio terapijos kompetencijų vertinimo metodiką“; V. Kukštienè, K. Letkauskinè ir G. Šniepienè (2014) - „Neformaliuoju būdu ịgytų grožio terapijos kompetencijų vertinimo ir pripažinimo metodiką". Vis dèlto grožio terapijos studijų praktika Lietuvoje ir siektinos kompetencijos iki šiol mokslininkų darbuose plačiai nenagrinejjamos.

Tyrimo objektas - grožio terapeutų kompetencijos.

Tyrimo problema: daugelio profesijų kompetencijų modelius apibrěžia Lietuvoje patvirtinti rengimo standartai, tačiau tokio grožio terapeuto rengimo standarto iki šiol nèra. Šiuo straipsniu siekiama nustatyti grožio terapeuto kompetencijų grupes, kurios ateityje galètų tapti pagrindu rengiant profesijos standartą.

Tyrimo tikslas: Lietuvos grožio terapeutų rengimo studijų programų pagrindu atskleisti grožio terapeuto kompetencijų grupes.

Uždaviniai:

- Atskleisti grožio terapeuto veiklos specifinius bruožus.

- Lietuvos grožio terapeutų rengimo studijų programų pagrindu išanalizuoti grožio terapeutų kompetencijų grupes.

Tyrimo metodai: mokslinès literatūros analizè, dokumentų analizè. 


\section{Grožio terapeuto veiklos specifika}

Grožio terapija jau daugeli metų yra tapusi multitautinės, multimilijonus uždirbančios grožio industrijos dalimi. Grožio terapeutų veikla, jos metodai, kompetencijos ir kvalifikacija yra tapę visuotinių diskusijų objektu medicinos, psichologijos, sociologijos ir kitų sričių specialistų darbuose (Black, 2002).

Grožio terapijos sąvoka gana išsamiai paaiškinta J. C. Segen (2005) sudarytame Medicinos žodyne - tai yra grožio priežiūros priemonių (pvz., veido odos priežiūros, šveitimo, kaukių, manikiūro, pedikiūro, depiliacijos ir kt.) taikymas, siekiant pagerinti asmens fizinę išvaizdą ir, idealiu atveju, kilstelèti jo savivertę. Remdamasis „Praktikos vadovu SPA organizacijoms“ (2010), grožio terapijos specialistas gali būti apibūdintas kaip kosmetologas, higienos ir dekoratyvinès kosmetikos technologas, kuris, siekdamas pagerinti žmogaus išvaizdą, naudoja ịvairias priemones ir būdus. Grožio terapijos specialistai, taikydami naujausias kosmetologijos procedūrų technologijas, kuria priemones ir metodus, kurie gali padèti išsaugoti sveiką veido ir kūno odą, pašalinti odos ir kūno defektus, išryškinti patrauklius veido bruožus, sukurti reikiamą ịvaizdį. Pažymėtina, kad literatūroje grožio terapijos elementai grupuojami įvairiai, tačiau, pavyzdžiui, Naujojoje Zelandijoje grožio terapeutus rengianti institucija "The National School of Aesthetics“ grožio terapiją skaido ị tris dideles grupes: veido, kūno priežiūrą ir depiliaciją. ${ }^{1}$ Pastebètina, kad greta grožio terapijos termino kaip paaiškinimas dažnai vartojama kosmetologijos sąvoka. Manytina, kad šių dviejų terminų kaip sinonimų vartojimas nèra klaidingas, nes esminis grožio terapeuto profesijos tikslas - kosmetologinių paslaugų teikimas.

Grožio terapeutai jau kelis dešimtmečius sẻkmingai rengiami daugelyje pasaulio šalių. Daugiau nei prieš 6 dešimtmečius Australijoje įkurtas E. Lukas grožio terapijos koledžas sẻkmingai veikia ir siūlo 20 grožio terapijos, masažo, makiažo, SPA terapijos kursų. Londono grožio terapijos koledžo absolventų ịsidarbinimo rodikliai gana aukšti. Grožio terapeutu poreiki pasauliniu lygmeniu įrodo ir sèkminga ịvairiu grožio terapeutų asociacijų veikla (pvz., Naujosios Zelandijos grožio terapeutų asociacija, Britanijos grožio terapeutų ir kosmetologų asociacija [BABTAC] - ilgiausiai veikianti ir sėkmingiausia grožio terapeutų ir kosmetologų asociacija, užtikrinanti savo darbuotojų profesionalią veiklą, šios asociacijos aktyviai veikia ir yra sulaukusios pripažinimo visame pasaulyje). Vien Didžiojoje Britanijoje dirba apie 85,5 tūkst. grožio terapeutų (Jocienè, Navikienè, Valiuliené, 2014, p. 6). Lietuvoje jų skaičius kasmet auga, nes matomos grožio paslaugų paklausos augimo tendencijos. Lietuvoje sveikatingumo ir grožio paslaugų sektorius 2005-2009 m. laikotarpiu vystėsi ypač sparčiai - apyvartos apimtys išaugo

1 Prieiga internete: http://www.nasa.co.nz/info. 
142 proc. nuo $17 \mathrm{mln}$. iki $42 \mathrm{mln}$. eurų. Net kriziniais $2009 \mathrm{~m}$. sektoriaus apyvarta augo 10 proc., palyginus su $2008 \mathrm{~m}^{2}{ }^{2}$ LR Ūkio ministerijos užsakymu atliktas taikomasis mokslinis tyrimas „SPA paslaugų klasifikavimo metodinès rekomendacijos“ (2009) atskleidè, kad grožio paslaugų rinka kasmet plečiasi, poreikis nemažèja. Siekdamos patenkinti darbo rinkoje atsiradusị grožio terapeutų poreikị, šiuos specialistus Lietuvoje rengia net kelios ugdymo institucijos.

Pagrindinės grožio terapeutų darbo vietos yra: SPA sveikatinimo, gydymo ir poilsio centrai, ambulatorinès klinikos, privatūs grožio salonai, privatūs ir valstybiniai kosmetikos kabinetai, kino ir fotografijos studijos. Grožio terapijos specialistai gali steigti ir specialias individualiąsias įmones, dirbti grimuotojais, konsultantais kosmetikos parduotuvèse bei kosmetologijos verslo įmonėse.

Analizuojant grožio terapeuto veiklos specifiką norètųsi akcentuoti ne tik šios profesijos specialistų poreikio augimą ir būtinybę ji patenkinti, bet ir pažymėti šių specialistų veiklos sudètingumą nuolat vykstančiu pokyčių sąlygomis. A. Lopaciuk ir M. Loboda (2013) teigia, kad pasaulinè grožio rinka yra didžiulè, atsižvelgiant ị pasaulyje suvartojamų produktų ir paslaugų kiekị. Kartu su gyvenimo būdo pokyčiais, technologijų plètra, keičiasi ir kosmetologija. Nors ši sritis, kaip ir anksčiau, tebėra odos, plaukų ir nagų puoselèjimas bei priežiūra, dabar, norint būti kosmetologu, reikia baigti mokslus, kurie atveria nemažai karjeros galimybių (Praktikos vadovas SPA organizacijoms, 2010). J. Lasauskienė ir A. Juvonen pabrèžia, kad ,pastaruoju metu sėkminga asmens veikla globalejjančiose organizacijose priklauso ne tiek nuo ịgytų baigus atitinkamą mokymo programą formalių kvalifikacijų, kiek nuo jo gebejimo adaptuotis kintančioje aplinkoje, kurioje esminis faktorius yra asmens kompetencija ir jos pletojimo potencialas" (2005, p. 29).

Kosmetologų teikiamos paslaugos yra gana ,jautrios“, tai ne tik grožio procedūrų atlikimas pagal taisykles, būtina sudaryti klientui malonias sąlygas, užmegzti su juo teigiamą ir glaudų, nors ir trumpalaikị, ryšį, leisti jam pailsèti (Black, Sharma, 2001). Pasak V. Isiūnienès, G. Adomavičienès ir Ž. Mickienès (2012, p. 188), kosmetologas yra ir savo profesijos menininkas, siūlantis klientui įvairius kūrybinius sprendimus. Vien talento neužtenka, kad šiandieniniame kosmetologijos pasaulyje grožio specialistą aplankytų sėkmè. Autorių nuomone, kosmetologai privalo turèti daugelio verslo sričiu žinių: bendravimo, žmonių tarpusavio santykių, prekybos rėmimo. O tai įmanoma pasiekti tik tuo atveju, kai grožio versle dirba kvalifikuoti ir kompetentingi specialistai. D. J. Staliūnienè pastebi, kad „tradiciškai mokslo sistema skirta dalykinėms kompetencijoms, vadinamoms „,kietosiomis“, formuoti; o „minkštosioms“ kompetencijoms (asmeninèms, socialinėms, emocinèms) skiriamas mažesnis dèmesys. Tačiau būtent pastarosios kompetencijos yra

2 Prieiga internete: http://www.brand4baltic.lt/lt/2011/grozis-ir-sveikatingumas/ sektoriaus-apzvalga- 2 . 
strategiškai aktualios sparčiai besikeičiančiam verslo pasauliui ir sudaro prielaidas verslumui ugdyti““(2009, p. 100).

Teigiama, kad visiškai patenkinti darbdavių poreikius darbo jègos kompetencijų atitikimo konkrečiai darbo vietai atžvilgiu nepaprasta. Nes, pasak D. Andriušaitienès, „konkrečiai profesinei veiklai (pareigybei) reikalingos kompetencijos paprastai reikalauja ne tik pagrindinių teorinių žinių, praktinių gebejimų ir ịgūdžių, bet ir specifinių, su įmonès specializacija susijusių ir suformuotų pareigybių specifikos, reikalaujančios tam tikrų (kartais netgi unikalių) kompetencijų derinių“ (2013, p. 18). Darbo rinkos ir darbdavių poreikius galima patenkinti pagrindines teorines žinias, praktinius gebejjimus ir ịgūdžius ugdant atsižvelgus ị veiklos sistemos poreikius. J. Jocienė ir kt. (2014) pažymi, kad Lietuvoje vykdomose kosmetologijos ir grožio terapijos studijų programose studijų rezultatai suformuluoti atsižvelgiant ị grožio terapeutų praktikų ir darbdavių požiūrị bei užsienio šalyse vykdomas kosmetologijos ir grožio terapijos programas.

Apibendrinant grožio terapeuto veiklos bruožus galima teigti, kad šio specialisto siekis - naudojant ịvairias kosmetologines priemones ir būdus pagerinti žmogaus išvaizdą, padèti jam pasijusti geriau, neretai net kilstelèti savivertę. Grožio terapeutui būtina išsiugdyti ne tik svarbiausias profesines kompetencijas, bet ir turèti didelị bagažą bendrujų žinių - psichologijos, bendravimo su skirtingais žmonèmis ir pan. Be to, šios srities specialistas turi gebèti prisitaikyti prie nuolatinių jo veiklos pokyčių, kad gebètų patenkinti klientų lūkesčius ir išlikti darbo rinkoje, kuri nuolat siūlo naujus iššūkius.

\section{Grožio terapeutų kompetencijų grupès Lietuvos grožio terapeutų rengimo studijų programose}

Šiandieninè visuomenè, tenkinanti žinių ekonomikos diktuojamus poreikius, orientuojasi ị individą, gebantị savarankiškai kelti mokymosi tikslus ir ịgyti jam būtinas žinias (Gaidelis, 2011). Šiuolaikinio grožio terapeuto kompetencija bendraja prasme gali būti suvokiama kaip asmens galių pritaikymas tam tikroje praktinèje veikloje, kuri lemia efektyvų ir kokybiškesnį darbą.

M. Eraut (2000) požiūriu, kompetencijos tobulinimas yra visų ugdymo programų tikslas. Minètas autorius skiria 3 požiūrius, kaip gali būti ugdoma kompetencija:

- meistriško išmokimo, kai ribojamas teorijos vaidmuo ir pabrèžiamas asmens elgesys. Šiuo požiūriu kompetencijos akcentuojamos kaip ugdymo tikslas: dominuoja specializuoti tam tikros profesinės veiklos gebejjimai ugdant konkrečius ịgūdžius, kurių reikia darbe, ir pasiekiamas automatiškas jų pakartojimo lygis, laikantis nustatytų tos profesinès veiklos standartų. 
- bendrasis požiūris, kada siekiama nustatyti tobulos veiklos kokybę. Remdamiesi matavimų rezultatais ir nustatę nepakankamą kompetencijų lygi, ugdymo programų kūrẻjai parengia programas, kurių tikslas - užpildyti susidariusias kompetencijų spragas.

- kognityvinis konstrukcinis, akcentuojantis akademines studijas ir išryškinantis skirtumą tarp potencialaus individo gebejjimo veikti ir išreikštos elgsenos tam tikros veiklos kontekste (cit. remiantis Gaidelis, 2011, p. 98-99).

S. E. Bidwell (2000) ịsitikinimu, puikių rezultatų mokydamasis grožio terapeuto profesijos studentas gali pasiekti tobulindamas tam tikrus mąstymo ịgūdžius (žr. 1 pav.).

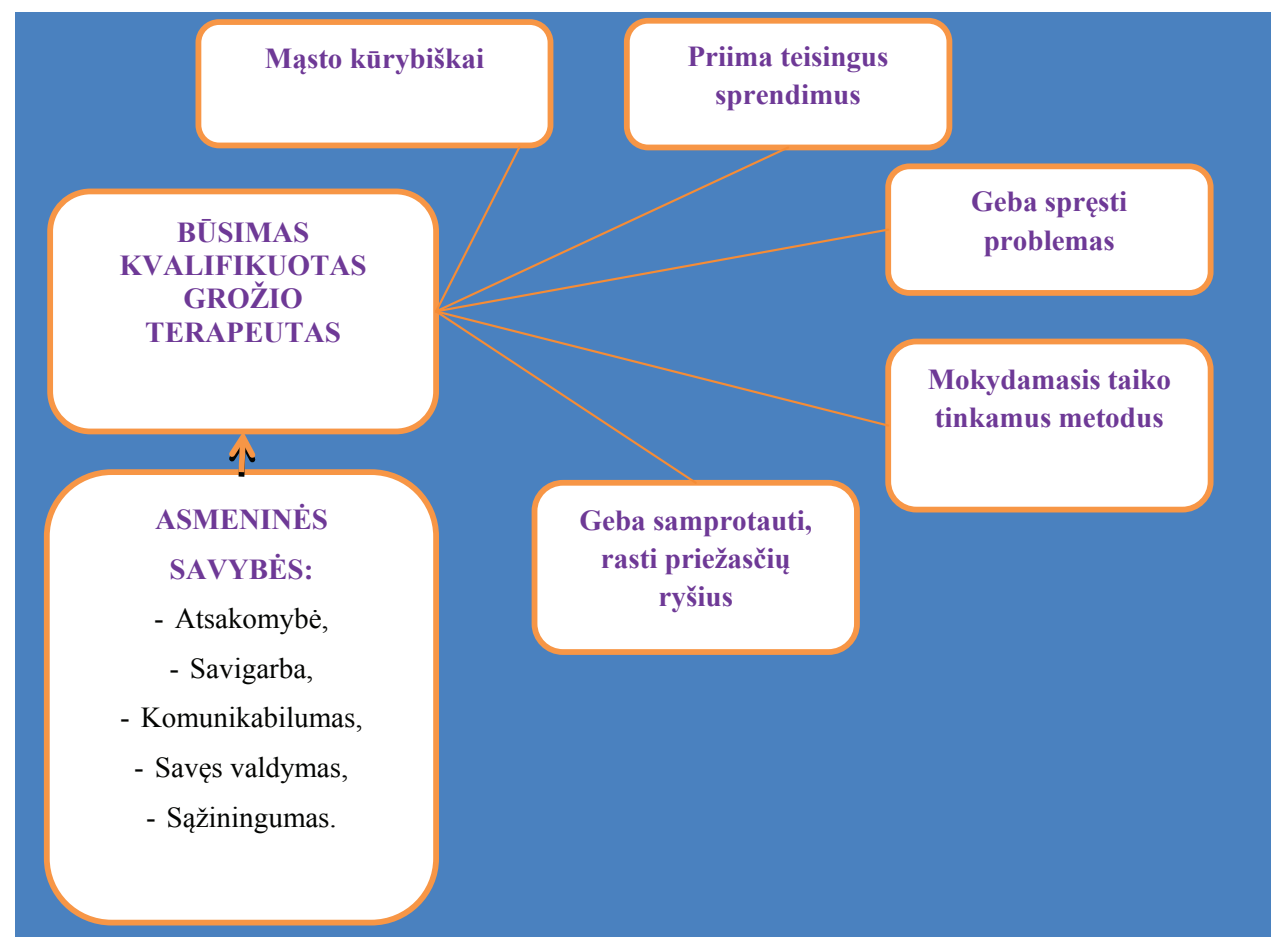

1 pav. Grožio terapeutui būtinos asmeninès savybès ir mąstymo igūūžiai

Pastaba: remiantis S. E. Bidwell (2000), sudaryta darbo autorių

S. Bidwell (2000) nuomone, grožio terapijos studentas visų pirma turi kūrybiškai mąstyti, t. y. ieškoti naujų idejjų. Pasak D. Lodienès, „vystant kūrybiškai minties veiklą yra kuriamos naujos idejjos. Naujos idejos brandina naujas technologijas. Naujų technologijų kūrimas ir vystymas visose srityse skatina progresą. Spartejantis progresas spartina pokyčius, o spartejantys pokyčiai skatina greičiau mąstyti bei vystyti minties veiklą. Spartejjanti minties veikla toliau spartina pro- 
gresą, dèl kurio dar labiau spartinamas ir pokyčiu greitis. Tokiu principu mes turime besikartojantị ciklą, kurio pradžia yra minties veikla, o rezultatas - progresas“ (2011, p. 38). Svarbu gebėti surasti tinkamus sprendimus, apsvarsčius visas imanomas perspektyvas, pašalinti kylančias problemas, turint konkretų veiksmų planą. Reikia nuolat mokytis, pasirenkant priimtinus ir daugiausiai teigiamų rezultatų duodančius mokymo metodus, gebèti logiškai samprotauti, ieškant priežastinių ryšių tarp ịvairių situacijų ir objektų. Be tobulinamų igūdžių, svarbios ir specialisto asmeninès savybès (žr. 1 pav.). Autorè mini 5 svarbiausias asmenines šios srities specialisto savybes. J. Jocienè su bendraautorėmis (2014) sąrašą papilde šiomis savybėmis: geranoriškumas, dėmesingumas, atsakingumas, gebejjimas priimti sprendimus, kruopštumas, savarankiškumas, kūrybingumas, komunikabilumas, sąžiningumas. Akivaizdu, kad minètų autorių sąrašai apima ir S. Bidwell (2000) pateikiamus mąstymo ịgūdžius bei asmenines savybes, kurie kaip bendra visuma sudaro sąlygas išugdyti kvalifikuotą grožio terapeutą.

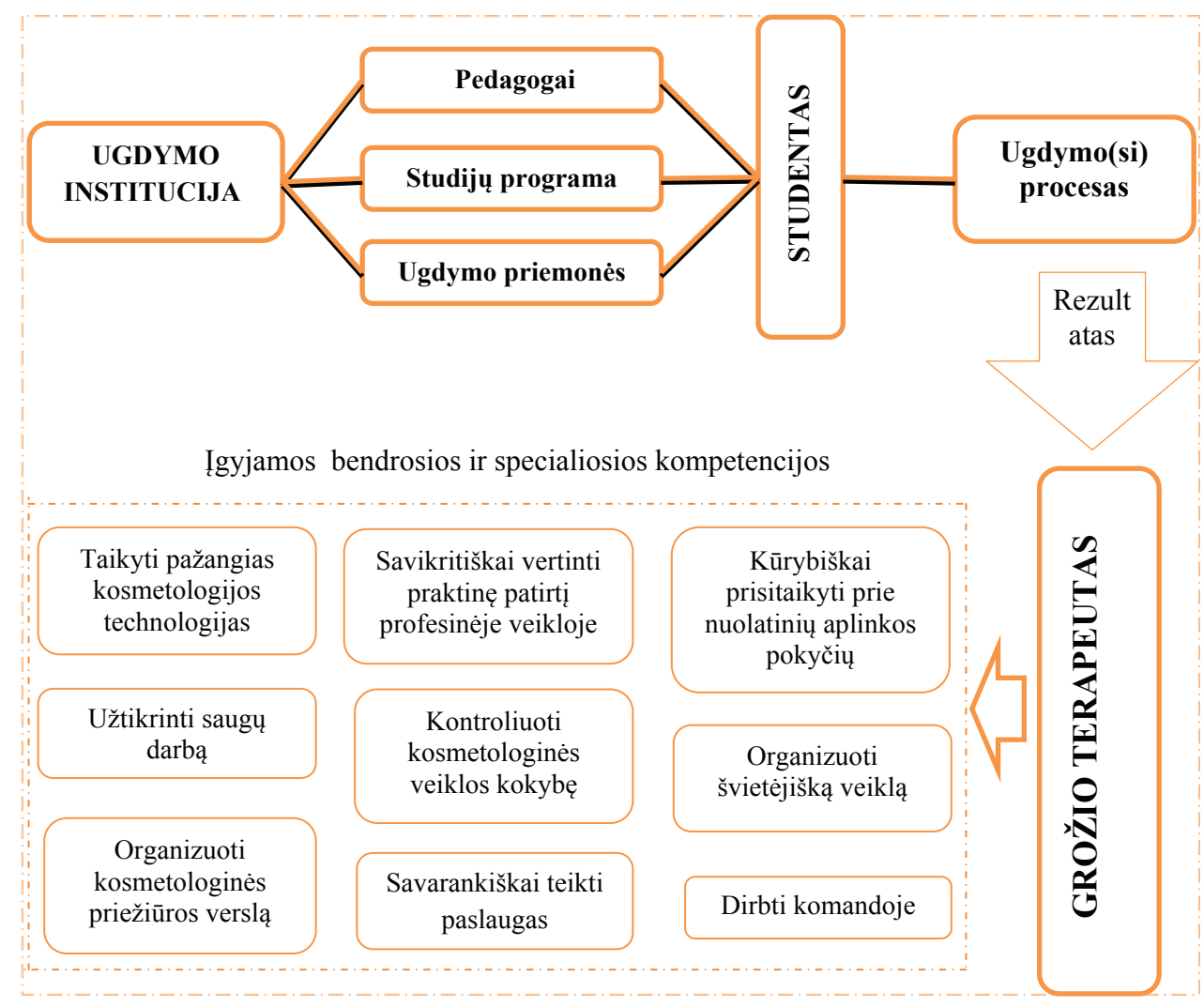

2 pav. Grožio terapeuto rengimas Lietuvoje

Pastaba: sudaryta darbo autoriu 
Lietuvoje grožio terapeutus (kosmetologus) rengiančios institucijos (Šv. Ignaco Lojolos, Utenos, Kauno kolegijos ir kt.) savo studijų programose išsikèlusios panašius ugdymo tikslus, kuriuose išryškejja būsimos specialisto bendrosios kompetencijos (žr. 2 pav.).

Grožio terapeutus rengianti institucija, pasitelkdama savo turimus išteklius (pedagogus, sukurtą studijų programą ir ugdymo priemones), siekia išugdyti kvalifikuotus grožio industrijos specialistus, kurie studijuodami igyja būtinas kompetencijas, ịgalinančias teikti kosmetologines paslaugas grožio, sveikatinimo ir sveikatingumo srityse.

Atsižvelgdamos ị pasaulinius grožio terapijos išsilavinimo ir profesijos standartus, grožio terapijos studijas organizuojančios institucijos remiamasi šiomis veiklos sritimis:

1. Kosmetologinių paslaugų teikimas grožio salonuose.

2. Mobiliujų kosmetologinių paslaugų teikimas nespecializuotose vietose.

3. Kosmetologinių priemonių ịrangos ir medžiagų naudojimas.

4. Kosmetologinès veiklos organizavimas.

5. Kosmetologinės kvalifikacijos kèlimas (Jocienè ir kt., 2014; Adomavičienè ir kt., 2010).

Išanalizavus grožio terapeutus rengiančių institucijų (Šv. Ignaco Lojolos, Utenos, Kauno, Klaipėdos valstybine kolegijos ir kt.) pateiktas studijų programas, galima nurodyti, kad ugdomos šios profesinès (specialiosios) kompetencijos (žr. 3 pav.).

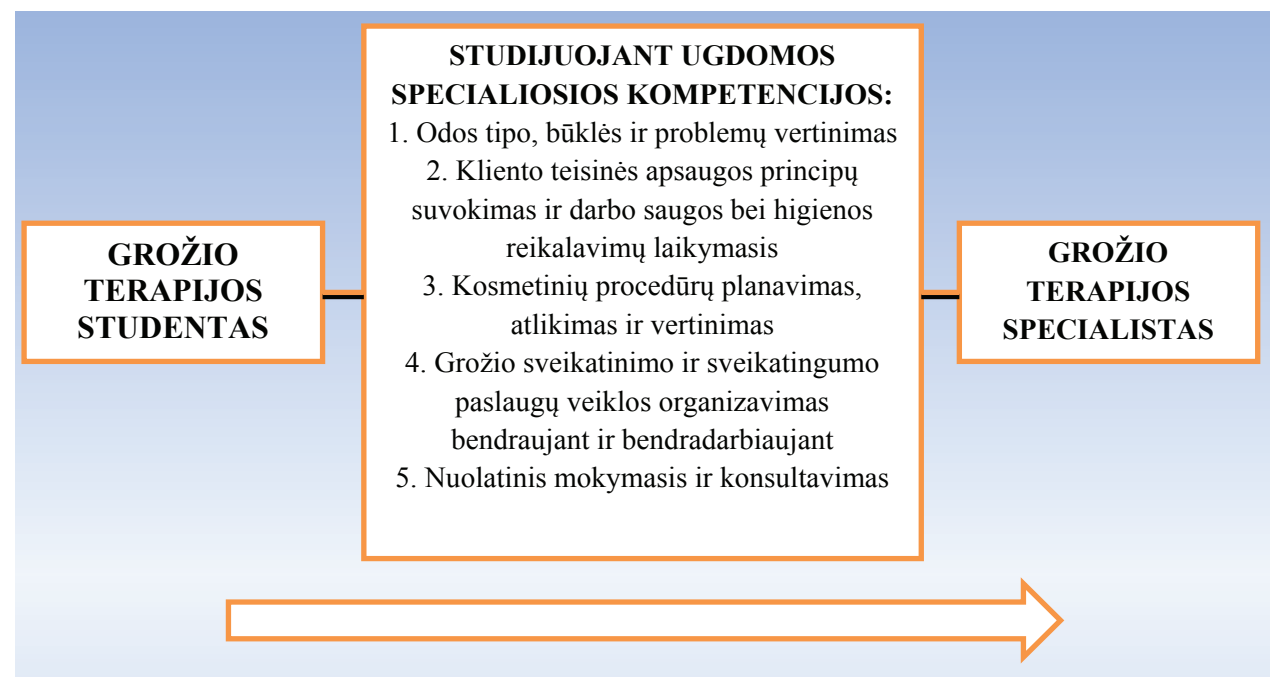

3 pav. Studijuojant grožio terapiją ugdomos specialiosios kompetencijos

Pastaba: sudaryta darbo autorių 
Žvelgiant į 3 paveiksle pateiktą informaciją matyti, kad grožio terapijos studentas grožio terapijos specialistu tampa igijęs pagrindines specialiąsias kompetencijas, tokias kaip: odos tipo, būklès ir problematikos vertinimo, kliento teisinès apsaugos principų suvokimo ir kt., nuolat mokydamasis ir konsultuodamasis.

1 lentelè. Grožio terapeuto kompetencijos, remiantis Šv. Ignaco Lojolos kolegijos grožio terapijos studijų programa

\begin{tabular}{|c|c|c|}
\hline & $\begin{array}{l}\text { Studijuojant } \\
\text { pasiektas } \\
\text { rezultatas }\end{array}$ & Rezultato apibūdinimas \\
\hline & $\begin{array}{l}\text { Igytos žinios, } \\
\text { gebėjimas jas } \\
\text { taikyti }\end{array}$ & $\begin{array}{l}\text { Grožio terapeutas turi praktini grožio paslaugų srities išmanymą } \\
\text { suteikiančiu naujausiais atradimais grindžiamų profesinès veiklos } \\
\text { (grožio terapijos procedūru parinkimo, organizavimo ir atlikimo, } \\
\text { žmogaus organizmo sandaros, funkciju ir patologijų, komunikacines } \\
\text { elgsenos, informacijos apdorojimo ir saugojimo) žinių, kurias geba } \\
\text { taikyti nustatydamas ir spręsdamas kompleksines konkrečias ar } \\
\text { abstrakčias veiklos srities problemas }\end{array}$ \\
\hline & $\begin{array}{l}\text { Gebėjimas } \\
\text { vykdyti tyrimus }\end{array}$ & $\begin{array}{l}\text { Geba suvokti taikomų tyrimu tikslingumą ir panaudojimą, rinkti, } \\
\text { analizuoti bei sisteminti duomenis, kurie būtini konkrečioms profesinès } \\
\text { veiklos ir inovaciju diegimo problemoms spręsti, vertinti gautus } \\
\text { rezultatus, analizuoti konkretaus užsakovo situaciją bei poreikius, } \\
\text { spręsdamas kosmetologijos ir grožio terapijos praktines problemas, } \\
\text { taikyti naujausias technologijas, analizuoti grožio srities bei profesinès } \\
\text { etikos dokumentus, rengdamas grožio priežiūros srities projektus }\end{array}$ \\
\hline & $\begin{array}{l}\text { Socialiniai } \\
\text { gebejjimai }\end{array}$ & $\begin{array}{l}\text { Geba konstruktyviai bendrauti ir bendradarbiauti su klientu bei jo } \\
\text { aplinka, kurti tarpdalykinio bendradarbiavimo ryši su kolegomis, } \\
\text { analitiškai, kritiškai ir kūrybiškai mąstyti organizuodamas ir teikdamas } \\
\text { kosmetologijos bei grožio terapijos paslaugas, taisyklingai reikšti mintis } \\
\text { lietuvių ir užsienio kalbomis žodžiu ir raštu, skleisdamas profesinę } \\
\text { patirtį ir konsultuodamas klientus, prisiimti etinę ir pilietinę atsakomybe } \\
\text { analizuodamas duomenis ir perteikdamas žinias, dirbdamas komandoje, } \\
\text { ieškodamas informacijos ir ją tvarkydamas, spręsdamas problemas }\end{array}$ \\
\hline & $\begin{array}{l}\text { Asmeniniai } \\
\text { gebėjimai }\end{array}$ & $\begin{array}{l}\text { Bendražmogiškosios savybès, paremtos humaniškumo nuostatomis } \\
\text { ir kriǩšioniškomis vertybėmis, asmeninio bei profesinio tobulèjimo } \\
\text { nuostatos, sprendimų prièmimas, analitinè veikla, kūrybiškumas, } \\
\text { komunikavimas, savarankiškumo ugdymasis, nauju specialistu } \\
\text { apmokymas, savo paties mokymosi bei profesinio tobulinimosi poreikiù } \\
\text { isivertinimas, atsakingumas, taisyklingas lietuviu ir užsienio kalbu } \\
\text { vartojimas ịvairioje socialinèje ir kultūrinèje aplinkoje, kultūringas } \\
\text { užsakovų aptarnavimas, kompiuterinis raštingumas }\end{array}$ \\
\hline & $\begin{array}{l}\text { Specialieji } \\
\text { gebėjimai }\end{array}$ & $\begin{array}{l}\text { Geba planuoti, organizuoti, vykdyti irvertinti praktinę veiklą konkrečiose } \\
\text { kosmetologijos ir grožio terapijos profesinès veiklos srityse: kūno, } \\
\text { rankų, peduu, plauku, visu grožio elementų susiejimo ị vieningą visumą, } \\
\text { savarankiškai pasirinkdamas technologines, organizacines ir metodines } \\
\text { priemones }\end{array}$ \\
\hline
\end{tabular}


Kaip matyti iš pateiktos lentelès, studijų siekiamybe - grožio terapijos studijas baigęs studentas turètų gebèti praktiškai pritaikyti ịgytas žinias, mokètų atlikti tyrimus, būtų ịgijęs socialinius gebejjimus, tokius kaip: komunikabilumas, konstruktyvus bendravimas, kūrybiškumas, atsakomybè. Ne mažiau svarbi yra specialisto vertybių sistema.

Baigęs studijas grožio terapeutas gebės numatyti ir pasiūlyti klientui reikiamas grožio paslaugas, sudaryti paslaugų teikimo planą, atlikti veido, kūno, nagų ir plaukų priežiūros paslaugas. Specialistas, igyvendindamas numatytą planą, pasitelks kosmetikos, kirpimo ir kitus grožio srities specialistus, dirbdamas su individualiais užsakovais ar vykdydamas užsakymus pramogų, paslaugų versle, sveikatos ir grožio srityse. Teikdamas grožio terapijos paslaugas specialistas gebės rinkti ir analizuoti su medicina, sveikata susijusią informaciją, vertinti medicinos ir sveikatos tendencijas, vykdyti taikomuosius tyrimus grožio sektoriuje, parinkti naujausias kosmetikos technologijas, naudotis pažangiausiomis informacinèmis technologijomis. Specialistas turès teisės ir verslo organizavimo žinių, gebės bendrauti ir bendradarbiauti. Grožio terapeuto igytos verslo organizavimo žinios ir gebèjimai skatins kurti individualų verslą. Grožio terapeutas turès bazinių psichologijos, profesinių vertybių, etikos, darbo komandoje žinių bei igūdžių, kuriuos gebės panaudoti ịvertindamas kliento poreikius, kurie susiję su fizinės išvaizdos gerinimu ir savivertès didinimu.

\section{Išvados}

1. Grožio terapeutą galima apibūdinti kaip kosmetologą, higienos ir dekoratyvinès kosmetikos technologą, kuris naudoja ịvairias priemones ir būdus, siekdamas pagerinti žmogaus išvaizdą. Grožio terapijos specialistai kuria priemones ir metodus, kurie gali padèti išsaugoti sveiką veido ir kūno odą, šalinti odos ir kūno defektus, išryškinti patrauklius veido bruožus, sukurti norimą ịvaizdị, naudodami naujausias kosmetologijos procedūrų technologijas. Grožio terapeutas, naudodamas ịvairias kosmetologines priemones ir būdus, siekia pagerinti žmogaus išvaizdą, padèti jam jaustis geriau, neretai net kilstelèti kliento savivertę. Grožio terapeutui studijuojant būtina išsiugdyti ne tik svarbiausias profesines kompetencijas, bet ir tureti didelị bagažą bendrujų psichologijos, komunikavimo su ịvairiais žmonėmis ir kt. žinių. Be to, šios srities specialistas turi gebeti prisitaikyti prie nuolatinių veiklos pokyčių, siekdamas patenkinti klientų lūkesčius ir išlikti darbo rinkoje, kur gausu iššūkių.

2. Lietuvoje grožio terapeutus rengiančios institucijos turi parengusios darbo rinkos ir būsimų grožio terapeutų poreikius atitinkančias studijų programas. 
Šiuo metu grožio terapijos profesinio bakalauro studijas siūlo Šv. Ignaco Lojolos, Kauno, Utenos, Vilniaus, Klaipédos valstybinė kolegijos ir keletas kitų. Grožio terapijos profesinio bakalauro studijos trunka 3 metus ir apima 120 kreditų. Grožio terapijos studentas tampa grožio terapijos specialistu igijęs pagrindines specialiąsias kompetencijas, tokias kaip: odos tipo, būklès ir problematikos vertinimas, kliento teisinès apsaugos principų suvokimas ir kt., nuolat mokydamasis ir konsultuodamasis.

Gauta 20150820

Pasirašyta spaudai 20151005

\section{Literatūra}

Adomavičienė, G., Mickienė, Ž., Vaikšnorienė, V. (2010). Kosmetologijos studijų programos siekinių / kompetencijų vertinimas profesinejje veikloje. Mokslo taikomieji tyrimai Lietuvos kolegijose 7: 105-108.

Andriušaitienė, D. (2013). Profesiniai standartai - galimybė derinti veiklos pasaulio ir švietimo sistemos poreikius. Verlas: teorija ir praktika 14(1): 17-26.

Bidwell, Sh. E. (2000). Project-Based Learning for Cosmetology Students. Ohio State University, Columbus, Center on Education and Training for Employment. Publications, Center on Education and Training for Employment.

Black, P. (2002). Ordinary People Come Through Here: Locating the Beauty Salon in Women's Lives. Feminist Review 71, Fashion and Beauty: 2-17. Prieiga internete: http://www.jstor.org/discover/10.2307/1396018?sid $=21106392434233 \&$ uid=2\&uid=3738480\&uid=2129\&uid=4\&uid=70 [žiūrèta 2014-12-02].

Gaidelis, A. (2011). Fizinio rengimo dėstytojų kompetencijos svarba rengiant teisèsaugos pareigūnus. Mokslinių straipsnių rinkinys. Visuomenés saugumas ir viešoji tvarka 6: 94.

Isiūnienè, V., Adomavičienė, G., Mickienè, Ž. (2012). Dirbančiųjų kosmetologijos specialistų kvalifikacijos kèlimo poreikis. Sveikatos mokslai 22 (5): 188-191.

Jocienè, J., Navikienė, Ž., Valiulienė, J. (2014). Kosmetologijos ir grožio terapijos kompetencijų vertinimo metodika. Metodinè priemonè. Panevėžys: UAB „Riprosetas“, 63 p.

Kukštienè, V., Letkauskinè, K., Šniepienè, G. (2014). Neformaliuoju būdu igytu grožio terapijos kompetenciju vertinimo ir pripažinimo metodika. Metodinè priemonė. Panevėžys: UAB „Riprosetas“, 51 p.

Lasauskienè, J., Juvonen, A. (2005). Muzikos mokytojų profesinė kompetencija: Lietuvos ir Suomijos studentų požiūris. Pedagogika 78: 29-35.

Lodienè, D. (2011). Progreso ciklą skatinantys veiksniai darnioje organizacijoje. Management theory and studies for rural business and infrastructure development 1 (25) [interaktyvus]. Prieiga internete: http://vadyba.asu. 1t/25/163.pdf [žiūrèta 2015-03-15].

Lopaciuk, A., Loboda, M. (2013). Global Beauty Industry Trends in the 21st Century. International Conference „Management, Knowledge and Learning “ [interaktyvus]. Prieiga internete: http://www.toknowpress.net/ ISBN/978-961-6914-02-4/papers/ML13-365.pdf [žiūrèta 2015-01-16].

Praktikos vadovas SPA organizacijoms. Grožio terapijos (kosmetologijos) specialistams ir ne tik. (2010). UAB Žmogaus studijų centras.

Savanevičienè, A., Stukaitė, D., Šilingienè, V. (2008). Development of strategic individual competences. Inžinerine Ekonomika - Engineering Economics 3: 81-88.

Sektoriaus apžvalga [interaktyvus]. Prieiga internete: http://www.brand4baltic.lt/lt/2011/sectors/grozis-ir-sveikatingumas/sektoriaus-apzvalga-2. [žiūrèta 2015-02-24].

Segen, J. C. (2005). Concise Dictionary of Modern Medicine. McGraw-Hill Professional Publishing.

SPA paslaugų klasifikavimo metodinès rekomendacijos. (2009). [Interaktyvus]. Prieiga internete: http://www. ukmin.lt/uploads/documents/imported/lt/veikla/veiklos_sritys/turizmas/Studijos/TAIKOMASIS $\% 20$ MOKSLINIS\%20TYRIMAS_SPA_2009.pdf [žiūrèta 2015-02-19]. 
Specialistu ir kompetenciju poreikio žemélapio studija. (2010). Galutinè ataskaita [interaktyvus]. Vilnius. Prieiga internete: http://www.smm.lt/uploads/lawacts/docs/39_e97d4269c8b7e8469225dab70eb114bf.pdf [žiūrèta 2015-03-23].

Staliūnienè, D. J. (2009). Rizikos įžvalgos teorinis tyrimas vidaus ir išorès audito technologijoje. Ekonomika ir vadyba 14: 100-107.

Helping you make an informed choice on beauty therapy. Prieiga internete: http://www.nasa.co.nz/info/ [žiūrèta 2015-02-21].

\title{
TRAINING OF SPECIALISTS OF BEAUTY THERAPY IN LITHUANIA: GROUPS OF COMPETENCIES OF BEAUTY THERAPISTS
}

\author{
Jūratė Jocienė, Alicija Ramanauskaitė
}

Summary

The demand for beauty therapy services are growing worldwide, it is a very popular speciality between labor market and young people who choose profession. A number of higher education institutions in Lithuania offers a professional bachelor's degree in beauty therapy. This paper analyzes the specifics of the beauty therapist work, defines the special expertise developed during studies, since validated training standards in Lithuania defines many professional competency models, however such training standard for beauty therapist is not currently available. This article aims to reveal the competence group for beauty therapist, which could become the base for the preparation of professional standard. The article discusses the beauty therapist training in Lithuania, describes the required personal qualities and thinking skills and presents the competency groups for beauty therapists. Using various cosmetology tools and techniques beauty therapist aims to improve persons appearance, helps you feel better and often even increases clients self - esteem. It was found, that beauty therapy student becomes beauty therapy expert, when obtains the core competencies, such as: the assessment of skin type, condition and problems, the understanding of clients principle legal protection and etc. with no exception of continuing education and consultancy. During the studies beauty therapist must not only develop the most important professional competencies, but also have a significant baggage of general knowledge, such as psychology, communication with different types people and so on. 